\title{
Multiculturalism in 2000s Indonesian Literary Novels from the Perspective of Character Building \\ Sociology of Literature Study
}

\author{
Haris Supratno \\ Universitas Negeri Surabaya \\ Surabaya, Indonesia \\ harisupratno@unesa.ac.id
}

\author{
Kamijan \\ Universitas Negeri Surabaya \\ Surabaya, Indonesia \\ kamijan@unesa.ac.id
}

\author{
Resdianto Permata Raharjo \\ Universitas Negeri Surabaya \\ Surabaya, Indonesia \\ rezdyraharjo@gmail.com
}

\begin{abstract}
This study aimed at revealing and describing multiculturalism in Indonesian literary novels from the perspective of character building. Indonesian literary novels reflect multiculturalism from the perspective of character building. It means that there are many portrayals of activities, behaviors, and language features in the novels which reflect the multiculturalism of the characters that people can use as media for character building, especially for the future gold generation. Therefore, they can build Indonesia as a safe, peaceful, and prosperous nation. The multiculturalism in the novels studied describe the characters including Fahri, Ayyas, Yalena, Lenor, Anastasia, Aisha, Fahmi, Hamza, Ali, and Subki, who come from different nations, social status, culture, and religion, yet they can still live together with respecting each other, tolerance, and helping each other when there is one of them in need without looking at all the differences. They help each other due to their love to Allah and their willing to run Allah's commands. The character, attitudes, and behaviors of the characters in the novels who deal with respecting each other, appreciating each other, tolerance, and admitting the existence of other people from different nation, culture, and religion; can be an example and medium for multiculturalism education from the perspective of character building for the society, especially for the young generation. The result of this research can contribute to the development of literature theory generally, and literature sociology especially. Furthermore, it can contribute to the multiculturalism education from the perspective of character building for Indonesian society, especially the young generation.
\end{abstract}

Keywords-multiculturalism, multicultural literature, character building perspective

\section{INTRODUCTION}

Indonesian literary novels reflect various cultural social pehnomena taking place in the society both in the past and in the present time. Indonesian society is multicultural society consisting of various ethnics, languages, social statuses, cultures, and also religions; but they are able to live together. However, in this current time on which governor election will be held, there exist various different views dealing with the governor election and national or presidential election later, which emerge negative effects. Such things might trigger conflicts among society that will finally lead to instability of security, politics, social, economy, and cultures [1].

Indonesian literary novels in 2000s mostly reflect multiculturalism which deals with ethnics, languages, social statuses, cultures, and also religions. The multiculturalism is applied to the real life in society, nation, and country; that deals with power, clannish, education, social, ethics, endeavor, patience, and other Islamic values. [2-3]. The existence of multiculturalism in Indonesian literary works cannot be separated from the authors' awareness and views, which enable them to reflect the national history awareness in cultural context embedded in Indonesia as a nation with advanced multiculturalism as the era development.

The existence of literary works cannot be separated from the authors as the creators dealing with all the social phenomena occurring in the society. The authors, as part of the society, cannot be separated from the phenomena taking place in the society, both in the past and in the present time. It means that various issues in literary works basically inseparable with various issues occurring in society [5-10].

Multiculturalism literature is literature which talks about ethnics, races, religions, customs, behavior patterns, and habit it. In multiculturalism, despite the acknowledgement of diversity including ethnics, cultures, and religion; yet, there are three basic principles that multiculturalism needs to have comprising acknowledgement of the other group's existence, tolerance, equivalence, and equality before the law for other 
cultural group. Multiculturalism emphasizes more on the intercultural, international, and inter-religion correlation by appreciating each other, respecting each other, and acknowledging the existence of each other [11-13].

Multiculturalism in Indonesian literary novels can be used as media for multicultural education from the perspective of character building and can be used also to be part of national educational curriculum. Character building is very important that it has to be carried out chronically in integrated way within families, societies, schools, pesantren, or campuses. It has to be so since the society's condition today is degrading in terms of moral and ethics, and furthermore having bad habits for Indonesian people. Character building is taught in the form of habit and culture as ideas or behaviors in people's daily life including at school. Character building can be done in four ways comprising religiosity-based, culture-based, environment-based, and self-potential-based [14].

\section{DISCUSSION}

Indonesian literary novels reflect various multicultural phenomena occurring in society, both in the past or in the present time. Multicultural literature has existed in Indonesian literary novels since the era of Balai Pustaka which reflect the local culture that imprints values to be appreciated, respected, and employed in education with Bhinneka Tunggal Ika as the basis [15]. Moreover, since the era of Balai Pustaka, Indonesian literature novels has been talking about multiculturalism. Therefore, the existence of multiculturalism has existed since the era of colonization because in that era, there found a number of literary works discussing about the multiculturalism in Indonesian society context [16].

Indonesian literary novels in $2000 \mathrm{~s}$ mostly portray multicultural education and they really appreciate the diversity of cultures [17]. Multicultural education offers an alternative for education with diversity in society as the basis. [18]. Those novels mostly portray the correlation in multiculturalism in dealing with some contexts comprising nations, ideas, views, cultures, and religions. The characters have multicultural attitudes from the perspective of character building. For example, Fahri in the novel Ayat-Ayat Cinta, Ayyas in Bumi Cinta, and Abdul Jalil in Sang Pembaharu, Perjuangan dan Ajaran Syaikh Siti Jenar, Fahmi, Hamza,and Ali in Api Tauhid.

Multiculturalism which copes with different cultures, languages and nations are portrayed in the novel Ayat-Ayat Cita. The character of Fahri as Indonesian who lives in Egypt. He can live together with Egyptians without prioritizing the different cultures, languages, and nations. The relationship between them and the other colleagues from different country is also nice and harmonic. Their intercourse never problematizes the difference of culture, language, and nation they have. They are bond with one single identity as students of Al;Azhar. Fahri's relationship with his teacher is also good. Moreover, he is deemed as his teacher' golden child without seeing his social status.

Fahri has multicultural knowledge dealing his colleagues and teacher. In getting along with them, he never thinks about the different nation, culture, and religion that they have. $\mathrm{He}$ has a principle that his religion tells the followers to always do good deed to everyone, respect each other, love each other, and appreciate each other. Because of having those attitudes, he is loved by his teacher and his friends. It can be found in a quote of the novel, "This year, through the selective examination, he only accepts 10 students. I am one of those lucky students. I am the only foreign student and the only one from Indonesia. Therefore, no surprise that he regards me as his golden child. In addition, there is none of my Egyptian friends who is envy of it. They are all sympathetic towards me." [19].

Multiculturalism which deals with social status differences is portrayed in the novel Ayat-Ayat Cinta. As a spouse, Fahri and Aisha respect each other, appreciate each other, love each other, tolerate each other, and never hurt each other, even though they have different social status. Fahri is an Indonesian student who is very simple with meddle-low social status. Meanwhile, Aisha is a Germany whose parents are very rich. Her parents have a luxury house, the vein of which faces the Nil river. They also have a lot of depositos. However, Aisha respects and tolerate her husband. Aisha never looks him down due to his middle-low social status. At the same time, Fahri is a husband who love, respect, and appreciate his wife. As a wife, Aisha also love, appreciate, respect, and never hurt her husband.

The multicultural attitudes that Fahri shows, deals with tolerance seen when he was arrested. He does not want to eat the food his wife brings because the other people in his jail only eat crackers and drink water. Fahri's tolerance towards the other arrests is very high. It was proven by his saying: "For the fast break, I think I can't, I answered". "Why" "It is impossible for me to eat the food while the others in the same cell with me, only break their fast with only water and cracker with expired jubna" [20].

Multiculturalism which deals with differences is portrayed in the novel Ayat-Ayat Cinta. Egyptian people like to glorifying guests. They are also very friendly, kind, and loving. Their gentle character, and their attitudes towards guests and other humans are like Yusuf and Ya'kub's character as well as Syaikh Sya'rawi, Syaikh Muhammad [21].

Multicultural attitudes are also portrayed in the novel Bumi Cinta through the character of Ayyas. He loves helping people including helping Yelena when she is tortured and going to be killed by three masher men who are her customers. Ayyas helps Yelena without seeing their different nation, race, culture, and religion. He helps her because he wants to run the God's command. Therefore, when Yelena is going to make it up to him, Ayyas says that he has not done anything. He says he only does what Allah obliges him to do. Islam teaches its followers that helping and saving a life is the same like saving the entire humans' lives. It can be found in the following quotation, "...Islam teaches its followers that helping and saving a life is the same like saving the entire humans' lives" [22]. 
The multicultural attitude dealing with social status is prortrayed in the relationship between Yalena, Aunt Margareta, and Ayyas. Despite the different social status, nation, culture, and religion; they respect each other, appreciate each other and tolerate each other. In their daily social intercourse, Yalena and Aunt Margareta never problematize their social status difference. Moreover, Yelena regards Aunt Margareta as her own mother and Aunt Margareta regards her as her own daughter. Aunt Margareta and Ayyas are the ones saving Yalena when she is dying. In multiculturalism, identity issue is a significant issue since it deals with national issue [23]. The multicultural attitude is seen in the following data, "Aunt Margareta still accompanies them. They still treat Aunt Margareta as their own aunt. The different beliefs do not affect the harmony in their relationship with Aunt Margareta" (24) (Shirazy, 2010: 500).

The multicultural attitude dealing with different views about religion is also portrayed in Bumi Cinta. When Ayyas hears Western views towards Islam as an orthodox religion identical with violence, he does not get angry. He really appreciates the different views that Western people have towards him and his religion as Islam. However, he tries to straighten the Western views seeing that Islam is always spread through violence and swords. Ayyas explains that when Umar bin Khatab opened Yerussalem, only peace that Yerusalem people got. Umar bin Khatab came to Yerusalem with love and respect towards the priests and Yerusalem people. There was no church destruction, no murder, and no city or village destruction. Such image is appeared in the following data: "When Islam opens Yerusalem, Yerusalem people only got peace. Umar bin Khatab came to Yerusalem with love and respect towards the priests and Yerusalem people. There was no church destruction. There was no city or village destruction...." [25].

As Ayyas' multicultural attitude, even though Islam is negatively valued by Western people, he tries to straighten the wrong view in seeing Islam with full of awareness and tolerance. He is aware of the mistake since Western people have not studied Islam yet. Therefore, he soon explains the real role of Islam that it is rahmatan lil alamin. Islam is full of peace and love as well as respect, glorify, and appreciate women. Such thing can be found in the following quotation "Yvonne admits that Islam really glorifies women that it is far from the stereotype spread in Western which deems Islam as a religion which oppress women... In fact, Islam fondles women... Moreover, Islam clarifies that women are the poles of a nation and really heaven is under mother's foot palm" [26].

Ayyas' multicultural attitudes of helping others without seeing national, cultural, or religion differences as well as his wise and his control of anger when Islam as his religion is mocked, need to be followed Indonesian people and even other Islam people all around the world. Therefore, it can avoid radicalism in society. Ayyas is aware that others stereotype Islam as an orthodox religion because they have not understood Islam yet. Hence, they need to be given the right information about the real lesson in Islam. Islam is a rahmatan lil alamin religion, which means that Islam is a religion for everyone. Those who really understand Islam are the ones having multicultural characters like respecting each other, appreciating each other, tolerance, and acknowledging the existence of others who have different ethnics, nations, cultures, and religion.

Multiculturalism that deals with power and nation conflicts, is portrayed in the novel Sang Pembaharu, Perjuangan dan Ajaran Syaikh Siti Jenar written by Agus Sunyoto. Power fight and nation fight do not have to be solved through war since it will destroy the existence of human beings. Furthermore, thousands or even millions of people will be the victims of war like what happens in Middle East. The power and nation fight need to be solved peacefully through meeting involving both parties. The power and nation fight appear in the following data: "...Uncle Raden Kusen has declared that Pakuwan Caruban is no longer under Maharaja Sunda, but under Demak .... Of course, Raden Kusen's decision makes Sudanese people angry and almost causes a big war. Then, my dad decides to accommodate the problem through diplomation. .... After going through some meetings, finally both dissent parties come to an agreement ..." [27].

The problem solution of the power and nation fight can be used as an example for Indonesian society or the world's society to prioritize meeting in power and nation fight so they do not have to be solved through war which can destroy human civilization causing thousands and even millions people become the victims just like what happens in Middle East.

The novel entitled Api Tauhid portrays multiculturalism which deals with nation. Hamza is a student of Madinah University who comes from Turkey and have some best friends namely Fahmi, Ali, and Subki from Indonesia. Their friendship does not look at the different nation they have. The four of them respect each other, love each other, and help each other mainly when Fahmi is praying in Nabawi mosque and going to finish reciting Koran for 40 times. Ali really worries Fahmi's condition that he persuades him to go home and get rest at the dormitory. However, his good intention is rejected by Fahmi. Fahmi has a strong will to stay praying in Nabawi mosque and to finish reciting Koran until 40 times. After that, Ali's anxiety really happens. When Ali and Hamza visit Fahmi in the mosque, they find Fahmi is fainted. Fahmi then is taken to the hospital in Madinah. Ali and Subki always stay beside Fahmi while he is taken care in the hospital.

Loyalty in the friendship of Hamza, Fahmi, Ali, and Subki, can be an example for Indonesian people that friendship does not look at different nations. Although Hamzah is Turkish, but his friendship with Ali, Fahmi, and Subki is sincere. They love each other and help each other when there is one of them in need. Furthermore, they also advise each other [28].

Fahmi has a strong character. Fahmi's strength and persistency in staying praying in Nabawi mosque and finishing reciting Koran for 40 times can be used as a good example for today's young generation who do not really love Koran. Nowadays, it is hard to find youth who loves Koran and be able to finish reciting Koran for 40 times. Instead, 
today's generation prefer memorizing top singers' songs [29] and moreover there are many of them fall into alcoholic drinks drugs, and free social intercourse.

\section{CONCLUSION}

Indonesia is basically multicultural nation which, despite the difference of ethnics, cultures, and religions; they can still live by respecting each other, appreciating each other, tolerance, and acknowledging their different rights. However, recently Indonesia performs multicultural degradation, which means that multicultural view is getting worse due to the different views in governor or presidential election.

Most Indonesian literary novels contain multiculturalism due to the characters in the novels who live in Egypt, Moskva, and Madinah and have different background of nation, race, culture, and religion; but can still live together with the other society of Egypt, Moskva, and Madinah. In their social intercourse, Fahri, Ayyas, Fahmi, and Hamza never problematize their national, racial, cultural, and religious differences. They have multicultural attitudes such as respecting each other, appreciating each other, and tolerant each other. When they help each other, they also never consider the national, racial, cultural, and religious differences. They help others because they want to run God's command.

Multiculturalism contains the values of respecting each other, appreciating each other, tolerate each other and acknowledging the existence of other cultural groups. Indonesian literary novels mostly express multiculturalism and it can be multicultural education media for building students' character so that they will have multicultural views that can be implemented in the multicultural society's life. The multicultural views comprise respecting each other, appreciating each other, tolerate each other, and acknowledge the right of existence of the other societies with different ethnics, nations, cultures, and religions.

The characters in Indonesian literatures who like to help others without seeing the national, cultural, religious differences as well as patient and wise in facing others who mock Islam that they follow, are good examples for Indonesian and the world's society in general. They can also be used as media to avoid any radicalism in any form including ideas, ideology, or behavior.

\section{REFERENCES}

[1] Al-Arifin."Pendidikan Multikultural-Religius untuk Mewujudkan Karakter Peserta Didik yang Humanis-Religius". Jurnal Pendidikan Iskam.Volume 1.Nomor 1. Juni. hlm.92, 2012.

[2] Rusmiati, Ana."Aspek-Aspek Budaya dalam Novel Ayat-Ayat Cinta Karya Habiburahman. Acintya. Volume 1, nomer 2, Desember 2009.

[3] Al-Maruf, Ali Imron."Peran Sastra Multikultural Sebagai Media Komunikasi Antarbangsa". Ejurnal Unej. Volume 1.No.1, Juni. hlm 3142 (http://ejurnal.unej.ac.id, 5 April 2016),2011.

[4] Al-Maruf, Ali Imron."Peran Sastra Multikultural Sebagai Media Komunikasi Antarbangsa". Ejurnal Unej. Volume 1.No.1, Juni. hlm 3142 (http://ejurnal.unej.ac.id, 5 April 2016), 2011.
[5] Wellek, Rene \& Austin Werre. Theory of Leterature. New York: Harcour \& Wolrd, 1968.

[6] Damono, Sapardi Djoko. Sosilogi Sastra, Sebuah Pengantar Ringkas. Jakarta: Pusat Pembinaana dan Pengembangan Bahasa Depdikbud,1984.

[7] Luxemburg, Jean Van,dkk Pengantar Ilmu Satra (Terjemahan Dick Hrtoko). Jakarta: Gramedia, 1984.

[8] Wolfreys, Yulian. Literary Theories A reader \& Guide. New York: New York University Press, 1999.

[9] Supratno, Haris. Sosiologi Seni, Wayang Sasak Lakon Dewi Rengganis dalam Konteks Perubahan Masyarakat di Lombok. Surabaya: University Press, 2010.

[10] Ratna, Nyoman Kutha. Sastra dan Cultural Studies: Representasi Fiksi dan Fakta.. Yogyakarta: Pustaka Pelajar, 2005

[11] Taufik, Ahmad. "Sastra Multikultural, Konstruksi Ideologi Kebangsaan dalam Novel Indonesia" (Disertasi). Surabaya: Pascasarjana Unesa, 2014.

[12] Ratna, Nyoman Kutha. Karya Sastra, Seni, dan Budaya dalam Pendidikan Karakter. $\quad$ Yogyakarta: Pustaka Pelajar, 2014

[13] Syarifudin, Achnad Fedyani."Membumikan Multikulturalisme di Indonesia". Jurnal Antropologi Sosial Budaya ETNVISI Vol.11.Nomor 1, April. Hlm 1-- 10 (http://repository.usu.ac.id, 5 April 2016), 2006.

[14] Hidayatullah, Yusuf " Nasionalisme dalam Novel ( Analisi Wacana Tentang Nasionalisme dalam Novel Bumi Mnusia Karya Pramudya Annta Toer)"(www: jurnal.comas.com, diakses 12 April 2016),2014.

[15] Amirin, Tatang M. "Implemenasi Pendekatan Pendidikan Multikultural Kontekstual Berbasis Kearifan Lokal". ". Jurnal Pembangunan Pendidikan: Pondas dan Aplikasi. Volume 1, Nomor 1, Juni. hlm.15, 2012.

[16] Taufik, Ahmad. "Sastra Multikultural, Konstruksi Ideologi Kebangsaan dalam Novel Indonesia" (Disertasi). Surabaya: Pascasarjana Unesa, 2014.

[17] Al-Arifin, Akhmad Hidayatullah. "Implementasi Pendidikan Multikultural dalam Praksis Pendidikan di Indonesia." Jurnal Pembangunan Pendidikan: Pondasi dan Aplikasi. Volime 1, Nomor 1, Juni. hlm 74-75 (http://e-jurnal.uny.ac.id, 5 April 2016), 2012.

[18] Hariyati, Nunuk. "Pengembangan Sekolah Berbasis Multikultural". Jurnal Pendidikan Humaniora. Vol. 2. No.4. Desember. hlm 38, , 2014.

[19] Shirazy, Habiburahman El. Ayat-ayat Cinta. Jakarta : Ihwah Publising Hause, 2005

[20] Shirazy, Habiburahman El. Ayat-ayat Cinta. Jakarta : Ihwah Publising Hause, 2005.

[21] Shirazy, Habiburahman El. Ayat-ayat Cinta. Jakarta : Ihwah Publising Hause, 2005.

[22] Shirazy, Habiburahman El. Bumi Cinta. Jakarta : Ihwah Publising Hause, 2011.

[23] Taufik, Ahmad. "Sastra Multikultural, Konstruksi Ideologi Kebangsaan dalam Novel Indonesia" (Disertasi). Surabaya: Pascasarjana Unesa, 2014.

[24] Shirazy, Habiburahman El. Bumi Cinta. Jakarta : Ihwah Publising Hause, 2012.

[25] Shirazy, Habiburahman El. Bumi Cinta. Jakarta : Ihwah Publising Hause, 2012.

[26] Shirazy, Habiburahman El. Bumi Cinta. Jakarta : Ihwah Publising Hause, 2012.

[27] Sunyoto, Agus. Sang Pembaharu, Perjuangan dan Ajaran Sayikh Siti Jenar. Jakarta: Gramedia, 2004

[28] Shirazy, Habiburahman El. Api Tauhid. Jakarta : Republika, 2014.

[29] Shirazy, Habiburahman El. Bumi Cinta. Jakarta : Ihwah Publising Hause, 2014 